\title{
Effect of Salt Stress on Growth and Mineral Elements Concentrations in Shoot and Root of Maize Plant
}

\author{
Süleyman TABAN 1 \\ Vahap KATKAT ${ }^{2}$
}

Geliş Tarihi: 01.06.2000

\begin{abstract}
Effect of soil applied $\mathrm{NaCl}$ on shoot and root growth and $\mathrm{Na}, \mathrm{Cl}, \mathrm{N}, \mathrm{P}, \mathrm{K}, \mathrm{Ca}, \mathrm{Mg}, \mathrm{Fe}, \mathrm{Zn}$ and $\mathrm{Mn}$ concentrations in shoot and root of the maize plant (Zea mays $\mathrm{L}, \mathrm{CV} ; \mathrm{RX} 947$ ) was investigated. The experiment was arranged in a completely randomized design with four replications under the greenhouse condition. The experimental soil was salinized with $\mathrm{NaCl}$ at the rates of $0,15,30,45$ and $60 \mathrm{mM} \mathrm{kg}^{-1} \mathrm{NaCl}$.

Shoot and root growth of the maize plants was inhibited by salinity. Increasing amount of $\mathrm{NaCl}$ application decreased the dry weight of shoot and root. $\mathrm{Na}, \mathrm{Cl}$ and $\mathrm{P}$ concentrations in the shoot and root increased with increasing amount of $\mathrm{NaCl}$. While applied $\mathrm{NaCl}$ caused to decrease $\mathrm{N}, \mathrm{Ca}$ and $\mathrm{Fe}$ concentrations in the shoot, to increase $\mathrm{N}, \mathrm{Ga}$, $\mathrm{Mg}$ and $\mathrm{Fe}$ concentrations in the root. $\mathrm{Zn}$ and $\mathrm{Mn}$ concentrations in the shoot and root were increased due to increasing amount of $\mathrm{NaCl}, \mathrm{Na}, \mathrm{P}, \mathrm{Mg}, \mathrm{Fe}, \mathrm{Zn}$ and $\mathrm{Mr}$ accumulated in the root in according with applied $\mathrm{NaCl}$.
\end{abstract}

Key Words: Maize, salt, growth of shoot and root, mineral elements, salt stress

\section{Mısır Bitkisinin Toprak Üstü Aksam ve Kök Gelişimi ile Mineral Madde Konsantrasyonu Üzerine Tuz Stresinin Etkisi}

Özet: Bu çalıșmada, misır (Zea mays L. cv: RX 947) bitkisinin toprak ustü aksam ve kök gelişimı ile toprak üstu aksam ve kökun $\mathrm{Na}, \mathrm{Cl}, \mathrm{N}, \mathrm{P}, \mathrm{K}, \mathrm{Ca}, \mathrm{Mg}, \mathrm{Fe}, \mathrm{Zn}$ ve $\mathrm{Mn}$ konsantrasyonu uzerine tuz $(\mathrm{NaCl})$ uygulamasinın etkis araştınimıștır. Tesadúf parselleri deneme desenine göre sera kaşullarında 4 tekrarlamalı olarak yürütülen denemede. topraklara $0,15,30,45$ ve $60 \mathrm{mM} \mathrm{kg}^{-1} \mathrm{NaCl}$ uygulanmiştır.

Artan miktarlarda uygulanan $\mathrm{NaCl}$ misir bitkisinin toprak üstū aksam ve kök gelişimini ve toprak üstù aksam lie kök kuru ag̈ırlıklarını azaltmıştı. Toprak üstu aksam ve kökün $\mathrm{Na}, \mathrm{Cl}$ ve $\mathrm{P}$ konsantrasyonları artan miktarlarda uygulanan tuza bağlı olarak artmış̧ır. Tuz uygulaması mısır bitkisinin toprak üstü aksamında $\mathrm{N}, \mathrm{Ca}$ ve $\mathrm{Fe}$ konsantrasyonlarınin azalmasına neden olurken, kökünde $\mathrm{N}, \mathrm{Ca}, \mathrm{Mg}$ ve $\mathrm{Fe}$ konsantrasyonlarının artmasına neden olmuştur. Toprak üstú aksam ve kökün $\mathrm{Zn}$ ve $\mathrm{Mn}$ konsantrasyonları artan miktarlarda uygülanan tuza bağlı olarak artmıştır. NaCl uygularrtesıyla $\mathrm{Na}, \mathrm{P}, \mathrm{Mg}, \mathrm{Fe}, \mathrm{Zn}$ ve $\mathrm{Mn}$ kökte akumule olmuştur.

Anahtar Kelimeler: Mısır, toprak üstù aksam ve kơk gelişimi, mineral madde, tuz stresi

\section{Introduction}

$\mathrm{NaCl}$ is usually the most injurious and predominant salt in the agricultural soils. Despite the essentiality of chloride as a micronutrient for all higher plants and of sodiurn as mineral nutrient for many halophytes and some $\mathrm{C}_{4}$ species the concentrations of both ions in saline substrates by far exceed this demand and lead to toxicity in non-salt-tolerant plants (Marschner, 1995). $\mathrm{NaCl}$ salinity causes to reduce vegetative growth, the rate of photosynthesis (Cusido et al, 1987) and also water availability and nutrient uptake by plants (Pessarakli and Tucker, 1988; Al-Karaki, 1996). Thus excessive uptake of mainly $\mathrm{Cl}$ or $\mathrm{Na}$ may lead to ionic disturbance of plants. Soil salinity increased $P$ (Yahya, 1998), $M n$ and $\mathrm{Zn}$ (Hasan et al., 1970 a,b; Chavan and Karadge, 1980), and decreased K (Siegel et al., 1980; Cusido et al., 1987), Fe and $\mathrm{Cu}$ (Hasan et al., $1970 \mathrm{a}, \mathrm{b}$ ) concentrations of plants. Shoots are generally more sensitive to cation disturbances than roots and there are great differences among plant species in the ability to prevent or tolerate to excess salt concentrations (Jeschke, 1982; Munns, 1993).
The objective of this work is to determine the effect of $\mathrm{NaCl}$ on shoot and root growth and $\mathrm{Na}, \mathrm{Cl}, \mathrm{N}, \mathrm{P}, \mathrm{K}, \mathrm{Ca}_{i}$ $\mathrm{Mg}, \mathrm{Fe}, \mathrm{Zn}$ and $\mathrm{Mn}$ concentrations in shoot and root of maize plant.

\section{Materials and Methods}

The experimental soil is non-calcareous $(0.58 \%$ $\left.\mathrm{CaCO}_{3}\right)$, clay in texture, slightly alkaline $(\mathrm{pH}, 7.42, \mathrm{E} . \mathrm{C}$.: $0.148 \mathrm{dS} \mathrm{cm}^{-1}$; both in water extract). The soil sample had $82.9 \mathrm{mg} \mathrm{kg}^{-1}$ exchangeable $\mathrm{Na}$. Water extractable $\mathrm{Cl}$ was $9.37 \mathrm{mg} \mathrm{kg}^{-1}$. The soil $(3000 \mathrm{~g})$ was placed into pots.

In the greenhouse experiment, for basal fertilizers, $100 \mathrm{mg} \mathrm{N} \mathrm{kg}^{-1}$ as ammonium nitrate and $80 \mathrm{mg} \mathrm{P} \mathrm{kg}^{-1}$ as triple super phosphate were applied to the all pots. The soil was salinized with $\mathrm{NaCl}$ at the rates of $0,15,30,45$ and $60 \mathrm{mM} \mathrm{kg}^{-1} \mathrm{NaCl}$.

Five maize (Zea mays L, cv: RX947) seeds were sown into each pot. After emergence, the plants were

\footnotetext{
Department of Soil science, Faculty of Agriculture, University of Ankara- Ankara

${ }^{2}$ Department of Soil science, Facuity of Agricullure, University of Uludağ-Bursa
} 
thinned to three. Plants were harvested six weeks after sowing and divided into shoot and root. All plant samples Were washed with distilled water, dried and weighed After grinding, all plant samples were digested with $\mathrm{HNO}_{3}: \mathrm{HClO}_{4}$ acid mixture (4:1) in order to determine $P$ $\mathrm{K}, \mathrm{Ca}, \mathrm{Na}, \mathrm{Mg}, \mathrm{Fe}, \mathrm{Zn}$ and $\mathrm{Mn}$ in the shoots and roots. Nitrogen was determined by a Kjeldahi digestion method. $P$ was determined colorimetrically by vanadomolybdate phosphoric yellow color method. $\mathrm{Na}, \mathrm{K}$ and $\mathrm{Ca}$ were determined by using Eppendorf Elex 6361 model flame photometry. $\mathrm{Cl}$ was analyzed by precipitation as $\mathrm{AgCl}$ and titration according to Johnson and Uirich (1959), Mg. Fe. $\mathrm{Zn}$ and $\mathrm{Mn}$ were determined by AAS (Philips model 9200x).

The pot experiment was arranged in a completely randomized design with four replicates. Analysis of variance of data for all parameters was computed using MINITAB computer package. MSTAT package was used for calculating Duncan's Multiple Range Test.

\section{Resuit}

Shoot and root dry weights of maize plant: Both shoot and root dry weight resulfs (Table 1) indicate that growth was inhibited significantly $(p<0.05)$ with the $\mathrm{NaCl}$ doses. Maize plants grown at the low levels of $\mathrm{NaCl}(0,15$ and $30 \mathrm{mM}$ ) reached relatively higher dry weights and did not imply toxicity symptoms. At 45 and $60 \mathrm{mM} \mathrm{NaCl}$, the symptoms of salt toxicity were traced with growth depressions. As average, the treatments of $\mathrm{NaCl}_{3}$ and $\mathrm{NaCl}_{4}$ ( 45 and $60 \mathrm{mM} \mathrm{NaCl}$ ) caused to decrease the shoot dry weight by $30.33 \%$ and $44.57 \%$ and the root dry weight by $22.92 \%$ and $39.57 \%$, respectively, when compared with the conirol

Ion concentrations and distribution: Applying increasing amount of $\mathrm{NaCl}$ increased significantly $(p<0.01) \mathrm{Na}$ and $\mathrm{Cl}$ concentrations in the shoots and roots (Table 2). As a result of salinity. $\mathrm{Na}$ accumulated in the root lissue rather than that in the shoot tissue. On the other hand, $\mathrm{Cl}$ concentration in the shoot was found to be much more than that the root $\mathrm{Cl}$ concentration.

While applied $\mathrm{NaCl}$ significantly decreased nitrogen concentration in the shool $(\rho<0,05)$, increased in the root $(p<0.01$ ) (Table 2). Salinity caused to increase $P$ concentrations in the shoot and root, and $\mathrm{Ca}$ and $\mathrm{Mg}$ concentrations in the root $(p<0.01)$ decrease $K$ concentrations in the shoot and root and $\mathrm{Ca}$ concentration in the shoot $(p<0,01)$ (Table 2 and 3 ).

Table 1. Effect of $\mathrm{NaCl}$ treatments on dry weights (g por ${ }^{-1}$ ) of shoot and root of the maize plants

\begin{tabular}{|c|c|c|c|c|}
\hline Treatments & Shoot & Change, \% & Root & Change, \% \\
\hline $\mathrm{NaCl}_{0}$ & $23.67 \mathrm{a}$ & - & $12.13 \mathrm{a}$ & - \\
$\mathrm{NaCl}_{1}$ & $23.64 \mathrm{a}$ & -0.13 & $11.43 \mathrm{a}$ & -5.77 \\
$\mathrm{NaCl}_{2}$ & $21.39 \mathrm{a}$ & -9.63 & $11.21 \mathrm{a}$ & -7.58 \\
$\mathrm{NaCl}_{3}$ & $16.49 \mathrm{~b}$ & -30.33 & $9.35 \mathrm{~b}$ & -22.92 \\
$\mathrm{NaCl}_{4}$ & $13.12 \mathrm{c}$ & -44.57 & $7.33 \mathrm{c}$ & -39.57 \\
\hline $\mathrm{NaCl}$ & $*$ & & $* *$ & \\
\hline
\end{tabular}

* Significant at $\mathrm{P}<0.0$ level

Means followed by the same letter are not significantly diflerent (Duncan's Multiple Range Test, $P<0,01$ )
Increasing levels of $\mathrm{NaCl}$ decreased iron concentration in the shoot. On the other hand, applied $\mathrm{NaCl}$ induced a progressive absorption of iron in the root, zinc and manganese in the shoot and root $(p<0,01)$ (Table 4). As a result of salinity $\mathrm{Zn}$ and $\mathrm{Mn}$ accumulated in the root.

\section{Discussion}

Salinity inhibits the growth of plants by affecting both water absorption and biochemical processes (Cusido et al., 1987). Moreover, $\mathrm{NaCl}$ salinity causes to decrease the rates of net photosynthesis significantiy by negatively affecting $\mathrm{CO}_{2}$ assimilation and leads to decrease largely nutrient uptake, and finally growth of plants is getfing reduced (Lauchli, 1984; Seeman and Sharkey, 1986), In fact, in this study, the high levels of $\mathrm{NaCl}(45$ and $60 \mathrm{mM}$ ) inhibited shoot and root growth of the maize plants, on the contrary low levels of $\mathrm{NaCl}$ Al-Karaki (1996, 1997), Gunes ef al. (1996), Taban et al. (1999) reported that applied $\mathrm{NaCl}$ reduced dry weight of experimental plants. The suppression of plant growth under saline conditions may either be due to osmotic reduction in water availability or to excessive lon levels. The shoot growth was much more affected by salinity than was the root growth. Noble and Rogers (1993) reported that roots seemed to be more resistant to salinity than were plant foliage. It may be explained that in the higher levels of $\mathrm{NaCl}$, the osmotic effect could inhibit the growth of shoot.

Increasing levels of $\mathrm{NaCl}$ induced a progressive absorption of $\mathrm{Na}$ and $\mathrm{Cl}$ in both shoot and root agreeing with the result of Chavan and Karadge (1986); Cusido et al. (1987) and Gunes et al. (1996). Excessive $\mathrm{Na}$ concentration in plant tissue disturbs the nutrient balance. osmotic regulation and causes specific ion toxicity (Bernstein, 1963). Accumulated $\mathrm{Cl}$ in the root tissue disruptive of membrane uptake mechanisms, thus causing or permitting increased entry and translocation of $\mathrm{Cl}$ to the shoot tissue (Yousif et al, 1972)

As reported by Cordovilla et al (1995), $\mathrm{NaCl}$ decreased $N$ concentration in the shoot tissues. Salinity has a negative interference on the nitrogen acquisition and utilization (Lewis, 1986). The negative effect of $\mathrm{NaCl}$ on the nitroger concentration of plants could be explained by the antagonism between $\mathrm{Cl}^{-1}$ and $\mathrm{NO}_{3}^{-1}$ as reported by Kirkby and Knight (1977) and Wehrmann and Hahndel (1984)

On the contrary the results of Al-Karaki (1997) and Award et al. (1990), in this study, $\mathrm{NaCl}$ treatments increased $P$ concentrations in the shoot and root. This result is in agreement with the reports of Yahya (1998)

The increased shoot $\mathrm{P}$ concentration by applying $\mathrm{NaCl}$ may be due to the increased availability of phosphorus in the soil or synergistic effect of $\mathrm{Na}$, which is involved in $\mathrm{P}$ uptake and/or transport to the shoot (Grattan and Maas, 1988) 
Table 2. Effects of $\mathrm{NaCl}$ treatments on $\mathrm{Na}(\%), \mathrm{Cl}(\%), \mathrm{N}(\%)$ and $\mathrm{P}(\%)$ concentrations in shoot and root of the maize plants

\begin{tabular}{|c|c|c|c|c|c|c|c|c|}
\hline \multirow{2}{*}{ Treatments } & \multicolumn{2}{|c|}{ Sodium } & \multicolumn{2}{c|}{ Chloride } & \multicolumn{2}{c|}{ Nitrogen } & \multicolumn{2}{c|}{ Phosphorus } \\
\cline { 2 - 9 } & Shoot & Root & Shoot & Root & Shoot & Root & Shoot & Root \\
\hline $\mathrm{NaCl}_{0}$ & $0.01 \mathrm{~d}$ & $0.12 \mathrm{c}$ & $0.28 \mathrm{~d}$ & $0.26 \mathrm{c}$ & $1.58 \mathrm{a}$ & $0.92 \mathrm{e}$ & $0.24 \mathrm{c}$ & $0.17 \mathrm{e}$ \\
$\mathrm{NaCl}_{1}$ & $0.04 \mathrm{~cd}$ & $0.51 \mathrm{~b}$ & $2.87 \mathrm{c}$ & $2.06 \mathrm{~b}$ & $1.54 \mathrm{ab}$ & $1.03 \mathrm{~d}$ & $0.27 \mathrm{bc}$ & $0.24 \mathrm{~d}$ \\
$\mathrm{NaCl}_{2}$ & $0.07 \mathrm{c}$ & $0.54 \mathrm{~b}$ & $3.14 \mathrm{c}$ & $2.85 \mathrm{~b}$ & $1.52 \mathrm{ab}$ & $1.15 \mathrm{c}$ & $0.29 \mathrm{bc}$ & $0.38 \mathrm{c}$ \\
$\mathrm{NaCl}_{3}$ & $0.15 \mathrm{~b}$ & $0.83 \mathrm{a}$ & $3.98 \mathrm{~b}$ & $3.83 \mathrm{a}$ & $1.36 \mathrm{bc}$ & $1.29 \mathrm{~b}$ & $0.32 \mathrm{~b}$ & $0.58 \mathrm{a}$ \\
$\mathrm{NaCl}$ & $0.34 \mathrm{a}$ & $0.94 \mathrm{a}$ & $4.85 \mathrm{a}$ & $4.20 \mathrm{a}$ & $1.29 \mathrm{c}$ & $1.43 \mathrm{a}$ & $0.40 \mathrm{a}$ & $0.65 \mathrm{a}$ \\
\hline $\mathrm{NaCl}$ & $*$ & $*$ & $*$ & $*$ & & $*$ & $*$ & $*$ \\
\hline
\end{tabular}

"and *t Significant at $P<0.05$ and $P<0.01$ level, respectively

Means followed by the same letter are not significantly different (Duncan's Multiple Range Test, $P<0.01$ ).

Table 3. Effects of $\mathrm{NaCl}$ treatments on $\mathrm{K}(\%), \mathrm{Ca}(\%)$ and $\mathrm{Mg}(\%)$ concentrations in shoot and root of the maize plants

\begin{tabular}{|c|c|c|c|c|c|c|}
\hline \multirow{2}{*}{$\begin{array}{l}\text { Treat } \\
\text { ments }\end{array}$} & \multicolumn{2}{|c|}{ Potassium } & \multicolumn{2}{|c|}{ Calcium } & \multicolumn{2}{|c|}{ Magnesium } \\
\hline & Shoot & Root & Shoot & Rool & Shoot & Rool \\
\hline $\mathrm{NaClO}_{0}$ & $2.70 \mathrm{a}$ & $1.92 \mathrm{a}$ & $1.20 \mathrm{a}$ & $0.38 \mathrm{c}$ & 0.37 & $0.28 \mathrm{~b}$ \\
\hline $\mathrm{NaCl}_{1}$ & $2.12 b$ & $1.61 \mathrm{~b}$ & $0.86 \mathrm{~b}$ & $0.42 \mathrm{c}$ & 0.41 & $0.30 \mathrm{~b}$ \\
\hline $\mathrm{NaCl}_{2}$ & $1,94 \mathrm{c}$ & $1.53 \mathrm{~b}$ & $0.73 \mathrm{c}$ & $0.59 \mathrm{~b}$ & 0.34 & $0.46 \mathrm{ab}$ \\
\hline $\mathrm{NaCl}_{3}$ & $1.89 \mathrm{c}$ & $1.46 \mathrm{~b}$ & $0.65 \mathrm{~cd}$ & $0.79 a$ & 0.36 & $0.65 \mathrm{a}$ \\
\hline $\mathrm{NaCl}_{4}$ & $1.79 \mathrm{c}$ & $1.14 \mathrm{c}$ & $0.53 \mathrm{~d}$ & 0.89 a & 0,37 & $0.61 \mathrm{a}$ \\
\hline $\mathrm{NaCl}$ & $*$ & ** & $\#$ & $*$ & ns & * \\
\hline
\end{tabular}

** Significant at $\mathrm{P}<0.01$ level; ns. not significant

Means followed by the same letter are not significantly different (Duncan's Multiple Range Test, $\mathrm{P}<0.01$ ).

When $\mathrm{NaCl}$ was applied to the soil, $\mathrm{NaCl}$ decreased $\mathrm{K}$ concentrations in the soot and root in according with an antagonism between $\mathrm{Na}$ and $\mathrm{K}$ (Siegel et al., 1980). Cramer et al. (1985) showed that excess $\mathrm{NaCl}$ leads to the loss of When $\mathrm{NaCl}$ was applied to the soil, $\mathrm{NaCl}$ decreased $K$ due to membrane depolarization by sodium ions. As a result of salinity, $\mathrm{K}$ accumulated in the shoot as also reported by Siegel et al. (1980). High sodium concentration in the substrate or in the soil inhibits uptake and transport of $\mathrm{Ca}^{2+}$ and may therefore induce calcium deficiency in plants (Lynch and Lauchli, 1985). As a result, $\mathrm{Mg}$ accumulated in the root. $\mathrm{A}$ similar result was reported by Cordovilla et al. (1995).

Unlike the result of Maas et al. (1972) and Bhivare and Nimbalkar (1984), in this research, it was shown that $\mathrm{NaCl}$ decreased iron concentration in the shoot. These results are in agreement with Shrivastava et al. (1993) and Alpasian et al. (1998). Applied $\mathrm{NaCl}$ caused to increase iron concentration and accumulation in the root. Applying $\mathrm{NaCl}$ increased zinc and manganese concentrations in the shoot and root. Similar results were reported by Chavan and Karadge (1980); Martinez et al. (1987) and Alpaslan et al. (1998).

\section{Conclusion}

Applied low levels of $\mathrm{NaCl}$ did not affect the growth of maize plants. But high levels of $\mathrm{NaCl}$ inhibited the growth and caused to decreased dry weights of both organs. $\mathrm{NaCl}$ caused to decrease nitrogen, potassium, calcium and iron in the shoot tissue. $\mathrm{Na}, \mathrm{P}, \mathrm{Mg}, \mathrm{Fe}, \mathrm{Zn}$ and $\mathrm{Mn}$ accumulated in the root tissue in according with applied $\mathrm{NaCl}$.

Table 4. Effects of $\mathrm{NaCl}$ treatments on $\mathrm{Fe}\left(\mathrm{mg} \mathrm{kg}^{-1}\right), \mathrm{Zn}\left(\mathrm{mg} \mathrm{kg}^{-1}\right)$ and $\mathrm{Mn}\left(\mathrm{mg} \mathrm{kg}^{-1}\right)$ concentrations in shoot and root of the maize plants

\begin{tabular}{|c|c|c|c|c|c|c|}
\hline \multirow[t]{2}{*}{ Treatments } & \multicolumn{2}{|c|}{ Iron } & \multicolumn{2}{|c|}{ Zinc } & \multicolumn{2}{|c|}{ Manganese } \\
\hline & shoot & root & shoot & root & shoot & root \\
\hline $\mathrm{NaCl}_{0}$ & $95.9 \mathrm{a}$ & $78.9 \mathrm{~b}$ & $7.60 \mathrm{c}$ & $17.75 d$ & $70.2 \mathrm{c}$ & $743 c$ \\
\hline $\mathrm{NaCl}_{1}$ & $89,4 a b$ & $123.8 \mathrm{ab}$ & $9.35 \mathrm{bc}$ & $22.95 \mathrm{~cd}$ & $76.1 \mathrm{c}$ & $61.3 \mathrm{c}$ \\
\hline $\mathrm{NaCl}_{2}$ & $84.2 \mathrm{ab}$ & $197.9 \mathrm{ab}$ & $10.40 \mathrm{~b}$ & $28.33 \mathrm{bc}$ & $95.9 \mathrm{~b}$ & $1654 \mathrm{~b}$ \\
\hline $\mathrm{NaCl}_{3}$ & $81.8 \mathrm{~b}$ & $238.8 \mathrm{a}$ & $10.93 b$ & $33.80 \mathrm{ab}$ & $105.7 \mathrm{ab}$ & $169.1 \mathrm{~b}$ \\
\hline $\mathrm{NaCl}_{4}$ & $62.9 \mathrm{c}$ & 266.9 a & $13.55 \mathrm{a}$ & $38.40 \mathrm{a}$ & $116.8 \mathrm{a}$ & 257.4 a \\
\hline $\mathrm{NaCl}$ & ** & th & $*$ & \#* & $\Rightarrow$ & \$* \\
\hline
\end{tabular}

** Significant at $\mathrm{P}<0.01$ level

Means followed by the same letter are not significantly different (Duncan's Multiple Range Test, $P<0,01$ ). 
References

Al-Karaki, G N 1996. Response of three tomato cultivars to increasing sall stress. Mu'ta Journal of Research Studies 11: $23-38$ :

Al-Karaki, G.N 1997. Barley response to salt stress at varied levels of phosphorus. Journal of Plant Nutrition 20:16351643 .

Alpaslan, M. A. Günes, S. Taban, I. Erdal and C. Tarakcioglu, 1998, Variations in calcium, phosphorus, iron, copper, zinc and manganese contents of wheat and rice varieties under sall stress. Turkish Journal of Agriculture and Forestry 22 : 227-233.

Award, A.S. D.G.Edwards and L.C. Campbell,1990. Phosphorus enhancement of salf tolerance of tomato. Crop Science $30: 123-128$

Bernstein, L. 1963. Osmotic adjustment of plants to saline media. II. Dynamic phase American Journai of Botany 48: 909818.

Bhivare, V.N and J.D. Nimbalkar, 1984. Salt stress effects an growth and mineral nutrition of French beans. Plant and Soll 80: 91-98.

Chavan, P.D. and B.A. Karadge, 1980, Influence of safinity on mineral nutrition of peanut (Arachis hyogea L.). Plant and Soil $54: 5-13$

Chavan, P.D, and B.A. Karadge, 1986, Growth, mineral nutrition, organic constituents and rate of photosynthesis in Sesbania grandiflora L. grown under saline conditions. Plant and Soil 93: $395-404$.

Cordovilla, M.P. A, Ocana, F Ligero and C. Liuch, 1995. Salinity effects on growth anaiysis and nutrient composition in four grain legumes-rhisobium symbiosis. Journal of Plant Nutrition 18:1595-1609.

Cramer, G.R., A. Lauctili and V.S. Polito, 1985. Displacement of $\mathrm{Ca}^{2+}$ by $\mathrm{Na}^{+}$from the plasmalemma of root cell. A primary response to salt stress? Plant Physiology 79: 207-211.

Cusido, R.M. J Palazon, T. Altobella and C. Morales, 1987 Effect of salinity on soluble protein, free amino acids and nicotine contents in Nicotiona rustica L. Plant and Soil 102: 55-60.

Grattan, S.R., E.V. Maas, 1988. Effect of salinity on phosphate accumulation and injury in soybean 11 Role of substrate $\mathrm{Cl}$ and $\mathrm{Na}$. Plant and Soil 109: 65-71.

Gūneş, $A_{n}, A$ Inal and M. Alpaslan, 1996, Effect of salinity on stomal resistance, proline and mineral composition of pepper Journal of Plant Nutrition 19:389-396.

Hasan, N.A.K., J.VV. Drew. D. Knudsen and R.A. Oison, 1970a Influence of soil salinity on production of dry matter and uptake and distribution of nutrients in barley and corn. I Barley (Hordeum vulgare L.) Agronomy Journal 62: 43-45.

Hasan, N.A.K. JW Drew, D. Knudsen and R.A. Dison, $1970 \mathrm{~b}$ influence of soll salinity on production of dry matter and uptake and distribution of nutrients in barley and corn II. Corn (Zea mays L). Agronomy Jot mal 62; 46-48

Jeschke, W.D. 1982. Cation fluxes in excised and intact roots in relation to specific and varietal differences. pp $57-69$. In: M.R. Saric (ed), Genefic Specificity of Mineral Mutrition of Plants, Serbian Cademy of Sciences and Arts, Belgrade, U.K.
Johinson, C.M. and A. Ulich, 1959. Analytical methods for use in plant analysis. California Agricultural Experiment Station Bulletin, 765, pp. 44-45.

Kirkby, E.A. and A.H. Knight, 1977. The influence of the level of nitrate nutrition on ion uptake and assimilation, organic acid accumulation and cation anion balance if whole tomato plants. Plant Physiology 60:349-353

Lauchli, A. 1984, Salt exciusion: an adaptation of legume for crops and pastures under saline condition. pp 171-187 In: R.C. Stoples and G.H. Toenniessen (eds.), Salinity Tolerance in Plants. Strategies for Crop improvement. John Willey and Sons, Nr

Maas, E.V., G. Ogata and M.J. Garber, 1972. Influence of salinity on $\mathrm{Fe}, \mathrm{Mn}$ and $\mathrm{Zn}$ uptake by plants. Agronomy Journal 64: 793-795.

Marschner, H. 1995. Mineral nutrition of higher plants. Second edition, 10 889. Acadernic Press, London; New York.

Martinez, V., A. Cerda and G.A. Fernandez, 1987. Salt tolerance of four tomato hybrids. Plant and Soil 97: 233-242.

Munns, R. 1993. Physiological processes limiting plant growth in saline soils: Some dogmas and hypotheses. Plant Cell Environmental 16: 15-24.

Noble, C.L. and M.J.E Rogers, 1893. Response of temperate forage legumes to waterlogging and salinity, pp $473-496$ Ir: Pessarakli, M. (ed,), Handbook of Plant and Crops Stress. Marcel Dekker, Inc., NY, USA,

Pessarakli, M. and T.C. Tucker,1988. Dry matter yield and nitrogene ${ }^{5}$ uptake by lomatoes under sodium and chioride strees, Soil Sci. Sociely of American Journal 52: $698-700$.

Seeman, J.R and TD Sharkey, 1986. Salinity and nitrogen effects on photosynthesis, ribulose-1,5-bipnosphate carboxylase and metabolite poll sizes in Phaseolus vulgaris L. Plant Physiology 82: $555-560$.

Shrivastava, AK., R. Darash, S.P. Shukla, A. Kumar and G.B. Singh, 1993. Effect of $\mathrm{NaCl}$ induced salt stress on iron uptake, partitioning and accumulation in sugar cane. Sugar Cane 4: 17-21.

Siegel, S.M., B.Z. Siegel, d. Massey, P. Lahne and J Chen, 1980. Growth of corn in saline waters. Physiology Planta 50: $71-73$.

Taban, S., A. Güneş, M Alpaslan and H. Ozcan, 1999. Değişik misir (Zea mays $L$ cvs.) çeşitlerinin fuz stresine duyarliliklan. $\mathrm{Tr}$ Joumal of Agriculture and Forestry; Supplement 3 625-633.

Wehrmann, I, and R. Hahndel, 1984, Relationship between N and $\mathrm{Cl}$ nutrition and $\mathrm{NO}_{3}$ content of vegetables. Proceedings VI international Colloquium for the Optimization of Plant Nutrition: Montpellier, France, pp, 2,679-685.

Yahya, A. 1998. Salinity effects on growth and on uptake and distribution of sodium and some essential mineral nutrients in sesame. Journal of Plant Nutrition 21:14391451 .

Yousif, H.Y., F.T Bingham and D.M. Yermason, 1972, Growth, mineral composition, and seed oll of sesame (Sesamum indicum L.) as affected by $\mathrm{NaCl}$ Soil Science Society of American Proceeding $36 \quad 450-453$. 


\title{
Hava Akımlı Düzenlerde Kullanılabilen Eleklerde Bazı Aerodinamik Özelliklerin Belirlenmesi
}

\author{
Ramazan ÖZTURK' \\ Kâmil SAÇILIK ${ }^{1}$
}

Geliş Tarihic 01.06.2000

\begin{abstract}
Özel : Bu çalışmada, çeşitti hava akımli düzenlerde kullanılabilen eleklerin bazı aerodinamik özelliklerinin belirlenmesi amaçlanmıştı. Bu amaçla bir deney düzeni geliştirimiștir. Deneylerde, 5 farkı grupta oimak üzere 32 ayrı elek deneme materyali olarak kullanilmıştır. Oluşturulan deneme düzeninde elekler 4 farklı hava akımında denenmiştir. Deneylerde statik ve dinamik basınç değerleri öiçülerek sistemde oluşan basınç dạşümleri ve sürüklenme katsayıı değerleri belirlenmiştir. Hava akımıannin değișimine bağiı olarak basınç düșümủ ve súräklenme katsayısı arasındaki illşkiler incelenmiştir.
\end{abstract}

Anahtar Kelimeler : Elekler, basınç doşüma, aerodinamik 8zellikler, sürüklenme katsayısı

\section{The Determination of Some Aerodynamic Properties of Screens to be Used in Airflow-Systems}

\begin{abstract}
In this research, it has been determined some aerodynamic properties of several agricultural screens to be used in wind pressure systems. For this reason, a measuring unit was constructed. 32 agricultural screens at 5 different group have been compared in experiments. Tests have been occurred at four different airflow velocities. By measuring static and dynamic pressure, it has been determined pressure drop and coefficient of drag taken place in airflow-system. As aimlow velocities were changed, various relationship between pressure drop and coefficient drag was studied.
\end{abstract}

Key Words : Screens, pressure drop, aerodynamic properties, coefficient of drag

\section{Giris}

Tarimsal ürünlerin temizlenmesí ve siniflandirmasinda çeşitli fizikomekanik özelliklerden yararlanilmaktadır. Bu özelliklerin başııcaları; boyut özellikleri, aerodinamik ozellikler, hidrodinamik özellikler, sürünme katsayısı, yäzey yapısı, özgül ağırlık, mekanik ozellikler, elektriksel ve optik ozellikler olmaktadir (Eker 1983). Bunlar arasinda boyut ve aerodinamik ózellikler óncelikle ele alınan fizikomekanik özelliklerdir. Bu iki özellik, hava akımli düzenierde temel ayrım özellikleri olarak kullanilmaktadır. Diğer özellikler ise temel ayrım ozelliklerinin yeterli olmadiğı durumlarda başvurulan yardımcı ozellikler olarak kabul edilmektedir (Yağcıoğlu 1996). Tanmsal üranlerin temel ayrım ozelliklerine göre temizleme ve sinıflandirilmasında kullanilan makinalarda orünlerin ózelliklerìne bağlı olarak çeşitli tip ve yapida elekler kullanilmaktadir. Bu elekler, hava kanallı ayırıcılarda, vantilatörden sağlanan farklı verdilerdeki hava akımları içerisinde de çalışabilmektedir. Bu nedenle eleklerin aerodinamik özelliklerin belirlenmesi, eleklerin kullanıldığı tarım makinalarınin başarılı bir şekilde tasarımları için gerekli olmaktadır (Eker 1983; Evcim 1991).

Hava akımlı düzenlerde eleklerin aerodinamik ózellikleri, temizleme kalitesini etkilemektedir. Hava akımlı elek duzenlerinde elek takımı, vantilatórle birlikte bir unite olusturmaktadır. Bu tip düzenler özellikle sap, saman yaprak vb yabancı maddelerin ana karışım içerisinden ayrilması amaciyla kullanilmaktadir. Tinaz, tarar ve harman makinaları ile biçerdöverlerde kullanilan elek sistemleri, bu amaçla kullanılan elek düzenieri arasında siraianabilmek- tedir. Bu tip elek sistemlerinde ayırma ișleminin kalitesi, hava akıminin hizı ve doğrultusundan başka elek yüzeyine etki eden hava akımının düzgün dağılımına da bağlı olmaktadır. Bu sistemlerde hava akımının elekten geçerken karşılaşmış olduğu direnç nedeniyle ónemli basinç düsümleri ortaya çıkabilmektedir. Bu basinç duşâmlerinin belirlenmesi, sistemdeki enerji gereksinimlerinin hesaplanabilmesi açısından önemli olmaktadır (Baker and Shearin 1995; Teitel and Shklyar 1998).

Vantilatörler, hava akımlı düzenlerdeki gerekli hava akımını sağlamaktadır (Saçılık 1992). Bu amaçla kullanilan vantilatörler düşūk $(<1 \mathrm{kPa})$ veya orta $(1-3 \mathrm{kPa})$ basınç kademelerinde çalışmaktadir. Bu amaçla genellikle 4-6 kanatlı santrifüj vantilatôrler kullanilmaktadir (Evcim 1991). Vantilatör devir sayısı, sistemdeki verdiyi, basinci ve gûcô etkileyen en önemli parametre olmaktadır. Ayrıca çevre koșullan vantilatörün çalışma koşullarını oldukça etkilemektedir (Ayık 1985). Hava akımlt düzenlerde kullanilan vantilatórlerle birlikte eleklerin teknik ózelliklerinin birlikte incelenmesi oldukça ônemlidir.

Hava akımı elek içerisinden geçerken eleğin direnci nedeniyle basınç kaybına uğramaktadır. Bu basınç kaybı toplam delik alaninın ve deliklerin düzenlenişinin bir fonksiyonu olarak değişmektedir. Eleğin hava akımına karşı gösterdiği direnç aşağıdaki eşitlik ile bulunabilmektedir (Yağcıoğlu 1996):

\footnotetext{
Ánkara Oniv. Ziraat Fak. Tarım Makinaları Bölümu-Ankara
} 


$$
\Delta P_{\sigma}=\left(u_{1}^{2}-u_{2}^{2}\right) r_{h} / 2 g
$$

Bu eşitlikte:

$$
\begin{array}{l:l}
\Delta P_{e} & \text { Basinç düşümo, } \\
u_{1} & \text { Elekten ónceki hava akımınin hızı, } \\
u_{2} & \text { Elekten sonraki hava akımimn hızı, } \\
\gamma_{\mathrm{h}} & \text { Havanın özuăl ağıriğı, } \\
\mathrm{g} & \text { Yerçekimi ivmesidir. }
\end{array}
$$

$u_{1}$ ve $u_{2}$ hizlari arasindaki orana ise eleğin aerodinamik katsayısı adı verilmektedir.

Bu çalışmanın amacıni; hava akımlı dozenlerde kullanilan çeşitii eleklerin, eleme emsallerine ve yapısai özelliklerine bağlı olarak hava akımının elek içerisinden geçerken oluşturduğu basınç duşumlerinin ve buna bağlı olarak surukienme katsayilarinın belirlenmesi oluşturmuştur. Deneyler sonunda belirlenen basınç düşümleri ve süruklenme katsayıları için matematiksel modeller geliștirilmiştir.

\section{Materyal ve Yöntem}

Hava akımlı düzenlerde kulianilabilen çeșitli eleklerin bazı aerodinamik ozelliklerini belirleyebilmek için Şeki 1'deki ölçme sistemi oluşturulmuştur. Olçme sistemi, vantilatör ve hava iletim hatiarından oluşmaktadir. Sistemdeki hava akımi, Çizelge 1'de teknik ozellikleri verilen bir santrifoj vantilatōrden sağlanmıştır. Santrifoj vantilatơr hareketini, güca 4,8 BG olan bir elektrik motorlu hız değiştiriciden almaktadır. Hız değiștirici ile santrifoj vantilatör, bir kaplin ile bağlanmıştır (Saçilık ve Öztürk 2000).

Hava iletim kanalları $60 \times 80 \mathrm{~mm}$ dikdörtgen kesit alanina sahip olup, yatay boru uzunluğu 1,5 $\mathrm{m}$ düşey boru uzunluğu ise $1 \mathrm{~m}$ dir. Sistemde oluşan dinamik ve statik basıncin olçülmesinde, olçme alanı $314 \mathrm{~Pa}$ ve hassasiyeti $1,57 \mathrm{~Pa}$ olan iki adet alkollü mikromanometre kullanilmiştır,

Santriföj vantilatör tarafindan yaratılan hava akımi, sistemdeki dirençleri karşılayacak özellikte olmalıdır (Gökelim 1983). Bu yüzden ölçme düzeninde, eleklerin aerodinamik ózelliklerin belirlenmesi için, sistemde oluşan dinamik, statik ve toplam basınç farklan ôlçülmuş̧ư Ayrica ölçme sisteminde oluşan sürüklenme katsayiları da belirlenmiştir. Sücaklenme katsayısı $\left(C_{D}\right)$, her bir hava akıminda elek üzerine uygulanan basincın belirlenmesinde kullanilmaktadir (Kosmos et al 1993).

Toplam basınç, dinamik ve statik basincın toplamindan oluşmaktadır. Dinamik basıncın belirlenmesinde, alkollu

\begin{tabular}{|c|}
\hline 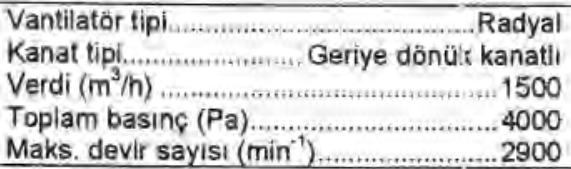 \\
\hline
\end{tabular}
dinamik basinç mikromanometresi ve pitot túpo kullanilmıştır. Tübülansli akışlarda, akışın rejim haline geçebilmesi için ölçme noktasının yeri (a), hava çıkış noktasından itibaren boru çapının 10 katından sonra

\section{Çizelge 1. Santrifäj vantilatöre ait teknik özellikler}

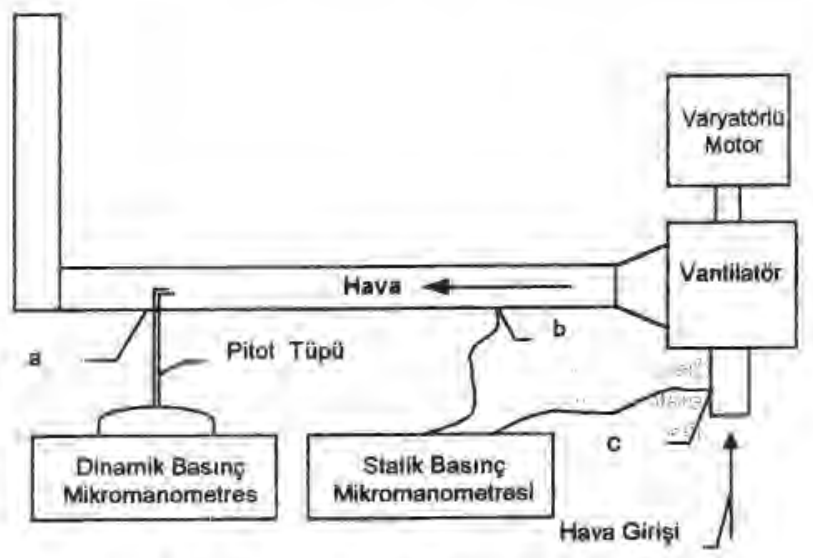

Şekil 1. Denemede kullanılan bilçme düzeni

olmaktadir (Beyhan 1992). Bu nedenle, vantilatördeki hava çıkıs noktası ile pitot tüpo arasındaki uzaklık $760 \mathrm{~mm}$ alınmıştır. Statik basınç ise, sistemde oluşan yersel kayıplari karşılamaktadır. Şekil l'de görülen b ve c noktalarına yerleştirilen basınç memelerinden alkolla statik basınç mikromanometresi lle statik basınç ólçŭlmüştör.

Denemeler dört farklı hava akımında $(7.15,7.97,8.88$, $9.72 \mathrm{~m}^{3} / \mathrm{s} \cdot \mathrm{m}^{2}$ ) gerçekleştirilmiștir. Her bir hava akımı için dinamik ve statik basinç değerleri ölçülmusşür. Her bir haya akimin da elekler üzerine etki eden dinamik basınç değerleri belirlendikten sonra sürüklenme katsayıları elde edilmiştir. Sürüklenme katsayılarının bulunmasında ise aşağıdaki eşitlik kullanılmıştır (Kosmos et al 1993):

$$
C_{D}=\frac{2^{*} P_{d}}{\rho^{*} V_{a}^{2}}
$$

Bu eşitlikte:

$$
\begin{array}{l:l}
\mathrm{C}_{0} & \text { Suruklenme katsayısı, } \\
\mathrm{P}_{\mathrm{d}} & \text { Dinamik basınç }(\mathrm{Pa}) \\
\mathrm{V}_{\mathrm{a}} & \text { Hava akımı }\left(\mathrm{m}^{3} / \mathrm{s} \cdot \mathrm{m}^{2}\right) \\
\rho & \text { Hava yoğunluğu }\left(\mathrm{kg} / \mathrm{m}^{3}\right)^{\prime} \text { dur }
\end{array}
$$

Geliştirilen olçme sisteminde çeşitli hava akımlı dôzenlerde kullanilabilen beş farkh grupta olmak uzere 32 elek denenmiştir. Her bir elek hava kanalı uzerine değişik aç farkli pozisyonda (birbirine dik ve çaprazlama olmak azere) yerleştirilmiştir. Ölçme sonuçları oç farklı konumun ortalaması olarak alınmıştır. Bir eleğin uzerindeki delinmiș alanların cokluğu elek açıklık katsayısı veya kısaca elek katsayısı ile tanımlanmaktadir. Bu katsayi, faydali delik alamının, toplam elek alanına oranı olarak verilmektedit. Bu katsayının büyumesi iş verimini artımaktadır. Bunun için birim elek youzeyine açılmış delik sayısının çok olması gerekmektedir.

Eleklerin geometrik ve teknolojik karakteristikleri delik şakillerine ve yapım malzemelerine bağh olarak değişiklik gostermektedir. Elekteki deliklerin dizilişleri, eleğin verdisini ve ayırma etkinliğini yakından Ilgilendirmektedir. Elek yüzeyinde birim alandaki delik sayısı ne kadai çok olursa tanelerin işlem sırasında herhangi bir deliğe rastlama olasılığıda o kadar artmaktadır. Denemelerde kullanilan eleklerin boyut ózellikleri ve eleme emsalleri Çizelge 2'de verilmiştir. 
Çizelge 2. Elek tipleri ve teknik özellikleri

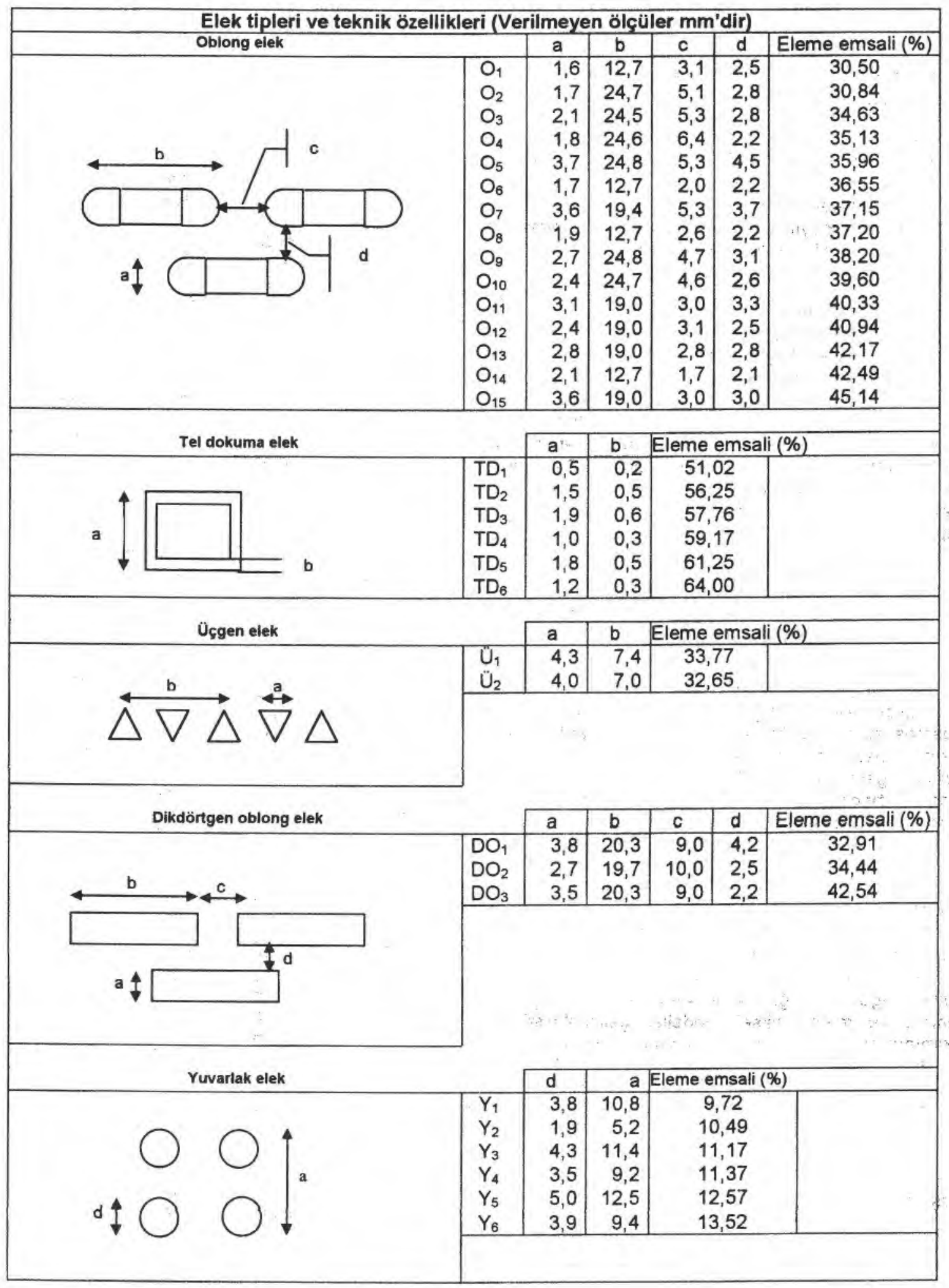




\section{Bulgular ve Tartışma}

Tarım makinalarında, hava akımlı düzenlerde kullanilan elekler farkı hava akımılarında çalışabilmektedir. Her bir elek için farklı hava akımında statik ve dinamik basınç değerleri belirlenmiş ve bunlara bağlı olarak $C_{0}$ katsayıları hesaplanmıştır. Denemelerde kullanilan elekler ıçin farklı hava akımlarında oluşan basınç dūsummleri ve sürüklenme katsayilarina ilișkin değerler Çizelge 3 ve 4 'te verilmiştir. Bu ilişkilere ait geliş̧tirilen matematiksel modellerin katsayıları ise Çizelge 5 ve 6 'da verilmiştir.

Basınç dusşumleri, hava akımının değişimine bağlı olarak üssel olarak değişmiștir $(p<0,01)$ :

$$
y=a x^{b}
$$

\section{Burada;}

$$
\begin{array}{l:l}
\text { y } & \text { Basınç duşümu }(\mathrm{Pa}), \\
x & \text { Hava akımı }\left(\mathrm{m}^{3} / \mathrm{s} . \mathrm{m}^{2}\right), \\
\mathrm{a}, \mathrm{b} & \text { Denklem katsayılarıdır. }
\end{array}
$$

Süroklenme katsayıları ise hava akımının değişimine bağı olarak polinomsal olarak deḡișmiştir $(p<0,01)$

$$
y=a x^{2}+b x+c
$$

Burada;

$$
\begin{array}{l:l}
\text { y } & \text { Basinç dåşumu }(\mathrm{Pa}), \\
x & \text { Hava akımı }\left(\mathrm{m}^{3} / \mathrm{s} \cdot \mathrm{m}^{2}\right), \\
\mathrm{a}, \mathrm{b}, \mathrm{c} \text { : Denklem katsayilarıdır. }
\end{array}
$$

Araştirma sonuçlanna göre eleklerin birim alandaki delik sayıları, bunların dağılımı ve boyutsal karakteristikieri basınç dusșumunañ ve buna bağli olarakta $C_{0}$ değerlerini geniş oranda etkilemiştir. Hava akımlı düzende eleklerin meydana getirdiği basınç duşâmünü, eleğin delik şekll, yapım malzemesi ve eleme emsali geniş oranda etkilemiştir. Benzer sonuçlara Kosmos et al (1993) da ulașmiştir.

Genel olarak elekler kendi gruplan içerisinde değeriendirildiğinde eleme emsali büyüdâkçe basınç düşümünün azaldığı görülmüşür. Farklı elek gruplarında olup birbirlerine yakin eleme emsaline sahip elekler birbirleri ile karşılaştırıldığında ise basınç duşumleri hakkında istatistiksel olarak bir yorum yapilamamıştır Bu sonuca Kosmos et al (1993), eleğe etkiyen kuvvetlerin sadece eleme emsallerinin bir fonksiyonu olmamas! şeklinde bir yorum getirmiştir. Elekler kendi gruplar arasında incelendiğinde, süruklenme katsayısi değerlerinin hava akımının artmasına bağlı olarak arttığı gơrülmüștúr.

\section{Sonuç}

Hava akımlı düzenlerde kullanilabilen 5 farklı grupta olmak üzere 32 adet eleğin deneme materyali olarak kullanıldığı bu çalışmada, farklı hava akımlanında eleklerde meydana gelen başınç düșümleri belirlenmiștir. Elde edilen değerlere bağlı olarak sŭrüklenme katsayıları saptanmış ve matematiksel modeller geliştirilmiștir. Hava akımının artmasına bağlı olarak basınç düșümünün ûssel, sürüklenme katsayısının ise polinomsal olarak arttığ görülmüştar. Oluşan basinç düşümünü, eleğin delik şekli,

\begin{tabular}{|c|c|c|c|c|}
\hline \multirow[b]{2}{*}{ Elek kodu } & \multicolumn{4}{|c|}{ Hava akimi $\left(\mathrm{m}^{3} / \mathrm{s} \cdot \mathrm{m}^{2}\right)$} \\
\hline & 7,15 & 7,97 & 8,98 & 9,72 \\
\hline $\mathrm{O}_{1}$ & 72,99 & 88.68 & 123,99 & 142.83 \\
\hline $\mathrm{O}_{2}$ & 69,85 & 83,19 & 118,50 & 134,20 \\
\hline $\mathrm{O}_{3}$ & 68,86 & 80,13 & 108,31 & 128,50 \\
\hline 0. & 66,35 & 79,56 & 107,32 & 121,45 \\
\hline $\mathrm{O}_{5}$ & 64,86 & 78,70 & 106,74 & 120,13 \\
\hline $\mathrm{O}_{\circ}$ & 62,43 & 77,00 & 105,32 & 118,07 \\
\hline $\mathrm{O}_{7}$ & 60,22 & 76,11 & 104,81 & 116,31 \\
\hline $\mathrm{O}_{8}$ & 58,35 & 74,82 & 103,24 & 115.99 \\
\hline $\mathrm{O}_{9}$ & 56,86 & 73,51 & 102,67 & 114,42 \\
\hline$O_{10}$ & 55,36 & 71,90 & 100,25 & 113,38 \\
\hline$O_{11}$ & 54,35 & 69,85 & 99,09 & 112,99 \\
\hline $\mathrm{O}_{12}$ & 53,71 & 68,10 & 98,60 & 111,42 \\
\hline $\mathrm{O}_{13}$ & 52,29 & 66,95 & 97,10 & 110,51 \\
\hline $\mathrm{O}_{1 .}$ & 51,22 & 65,12 & 96,05 & 109,38 \\
\hline $\mathrm{O}_{15}$ & 50,29 & 63,42 & 95,75 & 108,45 \\
\hline TD, & 64,35 & 74,51 & 94,18 & 108,31 \\
\hline $\mathrm{TD}_{2}$ & 58,27 & 71,20 & 85,40 & 98,47 \\
\hline $\mathrm{TD}_{3}$ & 55,71 & 68,28 & 80,19 & 90,12 \\
\hline TD & 50,13 & 63,34 & 75,26 & 83,90 \\
\hline$T D_{5}$ & 48,20 & 54.77 & 70,62 & 78,76 \\
\hline $\mathrm{TD}_{6}$ & 44,26 & 50,13 & 65,61 & 73,26 \\
\hline$\vec{U}_{1}$ & 80,05 & 97.32 & 136,55 & 159,31 \\
\hline $\mathrm{O}_{2}$ & 74,56 & 94,96 & 134,20 & 156,96 \\
\hline $\mathrm{DO}_{1}$ & 73.28 & 91.82 & 116,94 & 141,26 \\
\hline $\mathrm{DO}_{2}$ & 68,49 & 81,62 & 106,45 & 122,42 \\
\hline $\mathrm{DO}_{3}$ & 66,77 & 77,49 & 94,18 & 109,88 \\
\hline$Y_{1}$ & 76,42 & 91.68 & 123,99 & 144,40 \\
\hline$Y_{2}$ & 74,42 & 88,82 & 113,99 & 141,26 \\
\hline$\gamma_{3}$ & 72,91 & 84,33 & 103,99 & 131,26 \\
\hline$Y_{4}$ & 69,64 & 80,19 & 98,37 & 126,00 \\
\hline$Y_{5}$ & 66.35 & 77,05 & 92,24 & 118,50 \\
\hline$Y_{0}$ & 64,35 & 71,02 & 80,04 & 109,09 \\
\hline
\end{tabular}
yapım malzemesi ve eleme emsall etkilemiștir. Eleme emsallerinin artışına bağli olarak basınç doşümlerinin ve

\begin{tabular}{|c|c|c|c|c|}
\hline \multirow[b]{2}{*}{ Elek kodu } & \multicolumn{4}{|c|}{ Hava akımı $\left(\mathrm{m}^{3} / \mathrm{s} \cdot \mathrm{m}^{2}\right)$} \\
\hline & 7,15 & 7,97 & 8,98 & 9,72 \\
\hline$\sigma_{1}$ & 1,142 & 1,165 & 1,262 & 1,398 \\
\hline $\mathrm{O}_{2}$ & 1.046 & 1.072 & 1,150 & 1,265 \\
\hline $\mathrm{O}_{3}$ & 0.999 & 1,040 & 1,079 & 1,154 \\
\hline $\mathrm{O}_{4}$ & 0,981 & 0,995 & 1.065 & 1,095 \\
\hline $\mathrm{O}_{5}$ & 0,971 & 0,983 & 0,992 & 1,005 \\
\hline $\mathrm{O}_{6}$ & 0,969 & 0.977 & 0,985 & 0,985 \\
\hline $\mathrm{O}_{7}$ & 0,959 & 0,970 & 0,980 & 0.987 \\
\hline $\mathrm{O}_{8}$ & 0,948 & 0,961 & 0,972 & 0,981 \\
\hline $\mathrm{O}_{8}$ & 0,941 & 0,950 & 0,964 & 0.970 \\
\hline$O_{10}$ & 0,934 & 0,945 & 0,955 & 0,962 \\
\hline$O_{11}$ & 0,924 & 0,934 & 0,944 & 0,954 \\
\hline $\mathrm{O}_{12}$ & 0,915 & 0,923 & 0,936 & 0,945 \\
\hline $\mathrm{O}_{13}$ & 0,905 & 0,916 & 0,925 & 0,937 \\
\hline $\mathrm{O}_{14}$ & 0,890 & 0,905 & 0,914 & 0.923 \\
\hline $\mathrm{O}_{15}$ & 0,881 & 0,886 & 0,899 & 0,910 \\
\hline$T D_{1}$ & 0,985 & 0,997 & 1,022 & 1,125 \\
\hline $\mathrm{TD}_{2}$ & 0.951 & 0,981 & 0,999 & 1.086 \\
\hline $\mathrm{TD}_{3}$ & 0,932 & 0,953 & 0,984 & 0,991 \\
\hline $\mathrm{TD}_{4}$ & 0,910 & 0,930 & 0,954 & 0.980 \\
\hline $\mathrm{TO}_{5}$ & 0,881 & 0,895 & 0,925 & 0,960 \\
\hline $\mathrm{TD}_{6}$ & 0,863 & 0,876 & 0,896 & 0,916 \\
\hline $\mathrm{O}_{1}$ & 1,189 & 1,225 & 1,251 & 1.295 \\
\hline$\hat{U}_{2}$ & 0,996 & 1,172 & 1,195 & 1,125 \\
\hline DO, & 1,146 & 1,215 & 1,245 & 1,260 \\
\hline $\mathrm{OO}_{2}$ & 1,035 & 1,150 & 1.190 & 1,201 \\
\hline $\mathrm{DO}_{3}$ & 0,991 & 1.021 & 1,110 & 1,195 \\
\hline$Y_{1}$ & 1,145 & 1,180 & 1,195 & 1,201 \\
\hline$\hat{Y}_{2}$ & 1.050 & 1,151 & 1.182 & 1,192 \\
\hline$\gamma_{3}$ & 0,995 & 1,055 & 1,155 & 1,185 \\
\hline$Y_{4}$ & 0,981 & 0,890 & 0,995 & 1.150 \\
\hline$Y_{5}$ & 0,973 & 0,983 & 0,990 & 0,998 \\
\hline$Y_{\theta}$ & 0,960 & 0,970 & 0.982 & 0,989 \\
\hline
\end{tabular}
sürüklenme katsayısi değerlerinin azaldığı görülmüştur Eleme emsali birbirine yakın farklı elekklerde oluşan başınç duşumùne sadece eleme emsallerinin etkill olmadiğ gözlenmiştir.
Cizelge 3. Eleklerde meydana gelen basinç doșûmleri ( $\mathrm{Pa})$

Çizelge 4. Eleklerin süräklenme katsayiları 
Çizelge 5. Basınç düşümlerine ait matematiksel modelin katsayıları

\begin{tabular}{|c|c|c|c|}
\hline \multirow[b]{2}{*}{ Elek kodu } & \multicolumn{3}{|c|}{ Katsayilar } \\
\hline & a & b & $r^{2}\left(0^{*}\right)$ \\
\hline$O_{1}$ & 0,8328 & 2,2661 & 0,9913 \\
\hline $\mathrm{O}_{2}$ & 0,8442 & 1,2344 & 0,9841 \\
\hline $\mathrm{O}_{3}$ & 1,1065 & 2,0855 & 0,9696 \\
\hline $\mathrm{O}_{4}$ & 1,1878 & 2,0303 & 0,9921 \\
\hline$O_{5}$ & 1,0738 & 2,0808 & 0,9920 \\
\hline $\mathrm{O}_{3}$ & 0,9029 & 2,1517 & 0,9916 \\
\hline $\mathrm{O}_{7}$ & 0,7662 & 2,2206 & 0,9901 \\
\hline $\mathrm{O}_{6}$ & 0,6279 & 2,3066 & 0,9919 \\
\hline $\mathrm{O}_{9}$ & 0,5558 & 2,3566 & 0,9893 \\
\hline$O_{10}$ & 0,4933 & 2,4029 & 0,9924 \\
\hline$O_{11}$ & 0,4288 & 2,4615 & 0,9927 \\
\hline$O_{12}$ & 0,4089 & 2,4772 & 0,9890 \\
\hline$O_{13}$ & 0,3580 & 2,5318 & 0,9906 \\
\hline$O_{14}$ & 0,3185 & 2,5786 & 0,9887 \\
\hline$O_{15}$ & 0,2807 & 2,6313 & 0,9848 \\
\hline$T D_{1}$ & 2,1299 & 1,7248 & 0,9943 \\
\hline $\mathrm{TD}_{2}$ & 2,1278 & 1,6855 & 0,9985 \\
\hline $\mathrm{TD}_{3}$ & 2,7137 & 1,5432 & 0,9944 \\
\hline $\mathrm{TD}_{4}$ & 1,9683 & 1,6571 & 0,9881 \\
\hline $\mathrm{TD}_{5}$ & 1,7916 & 1,6647 & 0,9871 \\
\hline$T D_{6}$ & 1,4804 & 1,7168 & 0,9837 \\
\hline $0_{1}$ & 0,8260 & 2,3159 & 0,9919 \\
\hline $\mathrm{U}_{2}$ & 0,5546 & 2,4880 & 0,8858 \\
\hline $\mathrm{DO}_{1}$ & 1,1293 & 2,1194 & 0,9990 \\
\hline $\mathrm{DO}_{2}$ & 1,5128 & 1,9323 & 0,9961 \\
\hline $\mathrm{DO}_{3}$ & 2,7419 & 1,6167 & 0,9951 \\
\hline$Y_{1}$ & 1,1430 & 2,1279 & 0,9937 \\
\hline$Y_{2}$ & 1,2297 & 2,0742 & 0,9897 \\
\hline$Y_{3}$ & 1,7720 & 1,8746 & 0,9733 \\
\hline$Y_{4}$ & 1,6681 & 1.8804 & 0,9656 \\
\hline$Y_{5}$ & 1,8063 & 1,8179 & 0,9632 \\
\hline$Y_{6}$ & 3,6144 & 1,4505 & 0,9760 \\
\hline
\end{tabular}

\section{Kaynaklar}

Ayık, M. 1985. Ürün Işleme Tekniği ve Makinaları. Ankara Universitesi Ziraat Fakăltesi Yayınları No:957, Ankara.

Baker, J. R. and E. A. Shearin, 1994. An Update on screening for the exclusion of insect pests. N.C. Flower Growers Bulletin $39(2), 6-11$.

Beyhan, M. A. 1992. Olkemiz Koşullarına Uygun Aspiratörtö Bir Findik Hasat Makinası Tasarım Ve Imalatı. Ankara Üniversitesi Fen Bilimleri Enstitüü, Ankara. (Yayınlanmamı Doktora Tezi)

Eker, B. 1983. Tohum Hazirlama Makinaları. Turkiye Zirai Donatım Kurumu Mesleki Yayınları No:29, Ankara.

Evcim, O. 1991. Örün Temizleme ve Sınıflandırma Tekniği. Ege Üniversitesi Ziraat Fakültesi Yayınları No:500, Izmir.

Gökelim, A. T. 1983. Endüstriyel Fan ve Kompresör Tesisleri Birsen yayını $150 \mathrm{~s}$, Istanbul.
Çizeige 6. Sürüklenme katsayılarına ait matematiksel modelin katsayıları

\begin{tabular}{|c|c|c|c|c|}
\hline \multirow[b]{2}{*}{ Elek kodu } & \multicolumn{4}{|c|}{ Katsayilar } \\
\hline & a & b & c & $r^{2}(*)$ \\
\hline O, & 0,0432 & $-0,6304$ & 3,4410 & 0,9995 \\
\hline $\mathrm{O}_{2}$ & 0,0341 & $-0,4918$ & 2,8198 & 0,9982 \\
\hline $\mathrm{O}_{3}$ & 0,0134 & $-0,1691$ & 1,5258 & 0,9824 \\
\hline $\mathrm{O}_{4}$ & 0,0075 & $-0,0797$ & 1,1610 & 0,9709 \\
\hline $\mathrm{O}_{5}$ & 0,0006 & 0,0018 & 0,9259 & 0,9863 \\
\hline $\mathrm{O}_{6}$ & 0,0010 & $-0,0063$ & 0,9657 & 0,9938 \\
\hline $\mathrm{O}_{7}$ & $-0,0011$ & 0,0300 & 0,8028 & 0,9992 \\
\hline $\mathrm{O}_{8}$ & $-0,0011$ & 0,0313 & 0,7814 & 0,9975 \\
\hline $\mathrm{O}_{8}$ & $-0,0007$ & 0,0233 & 0,8091 & 0,9941 \\
\hline$O_{10}$ & $-0,0011$ & 0,0300 & 0,7778 & 0,9992 \\
\hline$O_{11}$ & 0,0003 & 0,0065 & 0,8631 & 0,9971 \\
\hline $\mathrm{O}_{12}$ & 0,0007 & $-0,0003$ & 0,8802 & 0,9989 \\
\hline $\mathrm{O}_{13}$ & 0,0006 & 0,0012 & 0,8642 & 0,9897 \\
\hline$O_{14}$ & $-0,0019$ & 0,0438 & 0,6727 & 0,9864 \\
\hline$O_{15}$ & 0,0025 & $-0,0308$ & 0,9729 & 0,9983 \\
\hline $\mathrm{TO}_{1}$ & 0,0335 & $-0,5146$ & 2,9582 & 0,9619 \\
\hline $\mathrm{TD}_{2}$ & 0,0211 & $-0,3090$ & 2,0854 & 0,9419 \\
\hline$T D_{3}$ & $-0,0042$ & 0,0946 & 0,4681 & 0,9873 \\
\hline $\mathrm{TO}_{4}$ & 0,0029 & $-0,0214$ & 0,9175 & 0,9978 \\
\hline $\mathrm{TO}_{5}$ & 0,0084 & $-0,1107$ & 1,2450 & 0,9997 \\
\hline$T D_{6}$ & 0,0031 & $-0,0314$ & 0,9306 & 0,9997 \\
\hline$\hat{U}_{1}$ & 0,0037 & $-0,0233$ & 1,1691 & 0,9815 \\
\hline $\mathrm{U}_{2}$ & $-0,0872$ & 1,5186 & $-5,4008$ & 0,9922 \\
\hline $\mathrm{DO}_{1}$ & $-0,0184$ & 0,3526 & $-0,4337$ & 0,9900 \\
\hline $\mathrm{DO}_{2}$ & $-0,0359$ & 0,6676 & $-1,8985$ & 0,9875 \\
\hline $\mathrm{DO}_{3}$ & 0,0221 & $-0,2933$ & 1,9550 & 0,9992 \\
\hline$Y_{1}$ & $-0,0099$ & 0,1881 & 0,3075 & 0,9912 \\
\hline$Y_{2}$ & $-0,0315$ & 0,5841 & $-1,5114$ & 0,9830 \\
\hline$Y_{3}$ & $-0,0081$ & 0,2135 & $-0,1231$ & 0,9874 \\
\hline$Y_{4}$ & 0,0908 & $-1,4613$ & 6,7842 & 0,9879 \\
\hline$Y_{5}$ & $-0,0005$ & 0,0178 & 0,8719 & 0,9900 \\
\hline$Y_{6}$ & $-0,0007$ & 0,0238 & 0,8273 & 0,9996 \\
\hline
\end{tabular}

Kosmos, S. R., G. L. Riskowski and L. L. Christianson, 1993. Force and static pressure resulting from airflow through screens. Transaction of the ASAE. Vol. 36(5), 1467-1472.

Saçilık, K. 1992. Tarım Makinalarinda Kullanılan Radyal Vantilatörlerin Bilgisayar Destekli Tasarımı. Ankara Üniversitesi Fen Bilimieri Enstitusô, Ankara. (Yayınlanmamıș Yüksek Lisans Tezi)

Saçilik, K. ve R. Öztärk, 2000. Biçim özelliklerine göre patatesin hava akımına karşı gösterdiği direncin belirienmesi. Tarım Bilimieri Dergisi: Vol.6(1), Ankara.

Teitel, M. and A. Shklyar, 1998. Pressure drop across insectproof screens. Transaction of the ASAE. Vol. 41(6), 18291834.

Yağcıoğlu, A. 1996. Ürün Işleme Tekniği. Ege Üniversitesi Ziraat Fakültesi Yayıniarı No:517, Izmir. 